\title{
TEACHER EDUCATORS AS PARTICIPANTS OF INTERNATIONAL PROJECTS: EXPERIENCE, CHALLENGES AND OPPORTUNITIES FOR THE DEVELOPMENT OF TEACHER EDUCATION
}

\begin{abstract}
Internationalisation is an integral part of the overall mission and strategy of higher education institutions. National, international and even global cooperativeness and partnerships have become indispensable components of teacher education institutions. The paper discusses the rationale for teacher educators' participation in international projects and reflects on the gains and lessons learnt from the participation in three multilateral projects. Findings suggest that any participation in partnerships should provide considerable benefits not only for the actively involved teacher educators and students, but also home institution, its departments, other colleagues and students who did not participate in the international project. More teacher educators and students gain experience abroad, broadening their understanding of the contemporary teacher education, more world and open-minded the faculty and student teachers become thanks to various project dissemination and follow-up events.
\end{abstract}

Keywords: collaboration, internationalisation, partnership, project, teacher education.

\section{Introduction}

Increasing interconnectivities, interdependencies, cultural interactions, moreover, competitiveness characterise the contemporary world (Cohen \& Kennedy, 2013), where the globalisation has led to "exposure to and contact with" (Greene, 2009, p. 328) differences on a greater scale, and cooperation is not always easy. Nevertheless, interaction, collaboration and partnerships with other like-minded institutions of the same or 
similar discipline is common in higher education. In other words, global cooperativeness, global competitiveness and internationalisation have entered the core aims of the university strategy and development.

Although Duffield, Olson and Kerzman (2013) consider that higher education institutions are not designed for collaboration with one another as they have their own individual mission, unique and recognisable identities, the necessity for collaboration and partnership building underlies the modernisation and internationalisation strategies. Changing student demographics, contemporary demands in the labour market for teachers, challenges that have resulted from the impact of economy, technology, politics and even business require the cooperation of teacher educators to become more aware of the concerns and search for multilateral solutions (Blūma, 2016). Husso, Korpinen and Asunta (2006) see that "networking and equal cooperation-partnerships are important starting points to create a new definition of teachers' professionalism with teachers' work changing from action alone to action together" (p. 116). Hence, this paper discusses the rationale for teacher educators' participation and collaboration in international projects.

When examining the collaboration of teacher education institutions in practice, first, it should be stated that it is a fundamental and strategic necessity to collaborate across departments and faculties within an institution to develop and realise qualitative teacher education programmes and interdisciplinary teaching opportunities. Second, it is essential to maintain an active collaboration with schools at all levels of education, other universities and higher education institutions, public, scientific, social and business organisations, NGOs, government, municipalities, and even media. Third, a collaboration with international partners, realising similar teacher education programmes, adds the international dimension to the goals of the institution. This means the international dimensions of curricula, a positive and efficient approach to foreign language learning, staff and student incoming and outgoing mobility, international partnerships to acquire research funding and complete collaborative teaching or research projects, networking, associations and consortia. Besides, with reference to European Commission (2013), an explicit internationalisation strategy must be an integral part of the overall mission and strategy of the individual higher education institution.

In this context the identity of teacher educators can be reviewed. Boyer (1990) reminds that teaching was the primary role of academics, historically; however, currently, their roles become increasingly complex (Blackmore \& Blackwell, 2003). Klecka, Donovan, Venditti and Short's (2008) research identified five facets of the identity of teacher educators: teacher, scholar in teaching, collaborator, learner and leader. Indeed, key 
responsibilities of teacher educators are multifaceted, covering such areas as teaching, consultancy, management, community of practice engagement, research and professional development (Boyer, 1990; Augstskolu likums, 1995-2018; Blackmore \& Blackwell, 2003; Higgs \& McCarthy, 2008; Blūma, 2016).

Besides, Eddy and Garza Mitchell's (2012) research shows that "changes in faculty work have led to an increased need for faculty members to garner research funding and other support in addition to regular teaching, service, and research duties" (p. 284). This is relevant to many higher education institutions; academic staff is invited to involve and generate more income from externally paid projects. Apparently, it is a pragmatic concern to excel in research, improve the attractiveness and obtain efficient enrolment rates in study programmes.

Looking from the dean's position, Jarchow (1997) states the necessity to establish and participate in international projects as the institution and its faculty can benefit considerably. First, teacher educators can take advantage of opportunities to keep up with those international changes that affect their discipline, develop their global competence, collaborating with multicultural teacher educators, meanwhile, think globally but act locally within their institution and community. Second, the institution's openness to international perspectives provides a better study experience for students: a global climate due to faculty exchanges, visiting scholars, incoming international students as a local resource to offer opportunity to learn more about the world, giving seminars on educational issues in their home countries; student study tours and summer schools where students can gain from hands-on activities with international participants. Third, Jarchow (1997) sees a benefit from joining organisations and consortia that focus on activities which can enhance the further development of the teacher education quality. Knowledge sharing, collaboration to excel in research, teaching and curriculum development, exchange of academic staff and students, cooperation between higher education, government and other sectors to develop a worldwide network of resources for innovative teacher education programmes are just few of activity examples.

Projects that cross borders can offer unique opportunities (Freedman \& Katz, 2007), when the gained international experience is valued, encouraged and supported (Eddy \& Garza Mitchell, 2012; Duffield, Olson, \& Kerzman, 2013) in the teacher education institution. Joining international initiatives, organisations and consortia related to higher education and pedagogy is worth endeavours to broaden the understanding of the contemporary teacher education, advance knowledge within disciplines of education, explore best practices and, as a result of collaborative projects, introduce and disseminate intellectual outputs, innovations and services 
that were not possible without the partnership. Creamer (2004) reveals that collaboration, especially if it is long-term, can move faculty members beyond individualistic thinking to global perspectives that challenge their preconceived notions of knowledge. Thus, collaborators are able to accomplish more together than they would have on their own, meanwhile, with reference to Heffernan and Poole (2005), providing a competitive advantage to an institution.

However, Eddy and Garza Mitchell (2012) consider the danger of an increased academic workload that could lead to dissatisfaction with one's faculty role and a lag in productivity. It cannot be denied that an active participation in any project requires additional time and increased workload to carry out project activities, make valuable contribution, attend meetings, moreover, be away from the home institution for some time.

As a teacher educator herself, the author can admit the considerable tension she senses between the teaching, research and project related opportunities and activities; each of them is time consuming, still crucial for the professional development. A clear definition of project goals and objectives can help to decide upon agreeing to join and contribute with one's endeavours and time. Besides, strong motivation, international interests and expertise in specific academic disciplines, openness, communication, trust and relationship commitment, identified long-term benefits of experience and loyalty to the home institution are aspects that can support teacher educators' decision to participate in international projects.

\section{Methods and Materials}

To explore the rationale for teacher educators' participation in international partnerships, this study presents an overview of theoretical underpinnings for collaboration in teacher education and uses a case study methodology, characterized as being particularistic, descriptive, heuristic in nature and with specific time boundaries (Merriam, 1998). The author introduces three cases of multilateral projects, she had the opportunity to be involved, and reflects on the gains and lessons learnt from the participation in them. The project analysis is done on the basis of project documents and evaluation reports, meeting minutes, project partners' and students' questionnaire results and the participant's observations during the project realization process.

Considering the teacher education institution's internationalisation efforts, the projects were selected according to the following criteria: the project had to be international; the teacher educators had opportunities for collaborative research and joint activities, furthermore, improving their professional skills and global competence; the teacher educators' 
professional development experience, gained during the international project, became a part of the prospective teachers' learning opportunity and development at the university. Thus, these three international projects contributed towards the professional development of a relatively large group of participants, i.e. faculty, international partners, above all, local and international students.

\section{Results and Discussions}

Case 1. To initiate a cooperation partnership for innovation and exchange of good practice a multilateral two-year project (2014-2016; ERASMUS + "Open the Door to Europe" Project No. 2014-1-ES01-KA204-004738) was carried out by six partners, representing universities, institutes and competence centres for adult education from Bulgaria, Germany, Italy, Latvia, Poland, Spain and Turkey. The aim of the partnership was to exchange experience and knowledge of foreign language teaching and meaningful gamification in education. Partners' collaboration resulted with a developed, tested and adapted e-learning platform with English, French, German, Italian, Spanish, Latvian, Polish, Bulgarian and Turkish six-unit language courses of job relevant linguistic and intercultural materials. The target audience was basic language users (A1, A2 levels, according to Common European Framework of Reference for Languages). The e-learning platform was supplemented with resource library for students and teachers, and a social network room for creating language tandems, i.e. an opportunity to practise the chosen language with native speakers.

Challenges: an increased workload; the in-depth research of meaningful gamification in education and the development of intellectual output of the project were time-critical; some issues of miscommunication, misunderstanding and commitment due to geographically and culturally diverse project colleagues, opportunely an effective and timely communication helped to clarify the critical issues.

Benefits of the teacher educator's professional development experience: expanded knowledge of gamification theory; improved technological skills through an online language course developing journey from an idea to its realisation, closely cooperating with project partners and platform system administrators; developed global competence, promoted in respectful and trust-based interaction with the diverse community of practice. Besides, the project partners were invited to participate in international teacheroriented conferences and workshops, based on their internationally-focused work.

Benefits for student teachers. First, a study course on modern technologies in foreign language studies was supplemented with a content 
on gamification; in practice, student teachers were encouraged to design their English lesson plans applying game elements and game design techniques in non-game contexts. There were students who decided to concentrate and explore further the gamification in language learning in their Term Papers. Second, a blended-learning course was offered for student teachers with basic English proficiency, thus they had an opportunity to develop a positive and constructive approach to effective oral and written communication for educational and self- improvement; moreover, they reflected and contributed in the process of testing the developed e-learning platform.

As the project occurred during the European migrant and refugee crisis, when more than a million migrants and refugees crossed into Europe in 2015, working together with professional learning communities to create the interdisciplinary online course became even more meaningful to support newly-arrived immigrants in the need of social and labour inclusion. Especially it was essential in those partnership countries which experienced the migrant and refugee crisis most of all.

Case 2. The case represents a partnership between universities, institutes and centres of research, innovation, language and competence development from Germany, Italy, Ireland, France, Latvia and Spain. The multilateral two-year project (2013-2015; Lifelong Learning Programme Project No. 543194-LLP-1-2013-1-ES-KA2-KA2MP) was carried out with an aim to address challenges of adult language learning. During the initial interaction phase the partnership was focused on the study to determine the needs of learners, language teachers and language centres for second and foreign language learning and oral expression practising in each partner country. Then a web platform containing interactive videos in English, French, German and Spanish languages was created to motivate adult learners to speak in their target language and improve oral language skills relevant to the job market.

The consortium partners transferred and further developed already existing learning platform, which was originally developed by the research group GHyM of the University of the Basque Country (Babelium Team, 2015). Face-to-face meetings and e-correspondence showed a strong impact on effective communication of project partners, especially during the video task piloting phase when even tiny but confusing technical issues were crucial to be detected, examined and tackled. Good collaboration within partnership was visible in small things.

Teacher educators and student teachers were involved to contribute during the piloting phase of the platform. Future English and German language teachers piloted videos with diverse exercises (e.g. storytelling, dubbing, conversation) for the development of communicative competences. 
In addition, they could make their own videos using simple tools (a webcam and microphone) and share with native speakers and other learners for assessment and improvement of their speaking skills, thus a collaborative learning in the network was encouraged, too. During seminars the students discussed the gained experience, provided feedback on the open-source collaborative educational tool, constructing a vision how they could use it in their teaching. Thus, the project encouraged a partnership between different teacher education study programme students and faculty within a home institution. Furthermore, an international conference was organised to introduce a wider community of teachers to different online learning tools for speaking practice in foreign languages.

Case 3. This international project (2014-2016; ERASMUS + Project No. 2014-1-TR01-KA203-011611) encouraged collaboration between teacher education universities from Croatia, Poland, Latvia, Slovakia and Turkey. The aim was to increase awareness among future language teachers of the value of learner autonomy and self-assessment; besides, the dissemination of the European Portfolio for Student Teachers of Language (EPOSTL) as a self-assessment tool and its electronic version was facilitated by partners.

Although the author of this paper was not a part of the team of two academics and eight students who were the delegated participants within the project from the home institution, this case was chosen to show the contribution of and benefits for the faculty and students during the preparation phase before two Intensive Programme (IP) meetings and project follow-up events.

The offered opportunity to join the project activities abroad could pose threats to the selected students due to their already full study schedules or provoke jealousy among other students, staying at home. Nevertheless, the faculty and fellow students worked as a team and helped to accomplish project related research assignments, e.g. students completed needs analysis questionnaires, teacher educators were interviewed and supervised the research papers, outgoing students carried out their researches, wrote reports, prepared presentations, which they practised presenting in front of their study mates. Everything required additional time commitment; however, the IP follow-up seminars let other students learn about the gained experience, best practices for self-assessment of student teachers' professional activities, thus they had an opportunity to learn and become more world and open-minded. Moreover, the collaborative learning resulted in Term Papers and Diploma Papers of student teachers, who had experienced their international mobility.

The selected cases of multilateral projects helped the author to illustrated how teacher educators and student teachers actually experience internationalisation, when being open to international cooperation and 
participation in joint educational and research projects. The cases point to the rationale for teacher educators' participation in international partnerships: to meet and collaborate with international community of practice in order to exchange specific experience and knowledge; to come up with joint research output, innovative teaching and learning methodology, approaches and tools, so bridging theory and practice; to address and meet the needs of student teachers and help them prepare for future employability, improving foreign language skills (Case 1), exploring technology enhanced language learning innovations (Case 2) or increasing one's awareness of the value of learner autonomy and teacher self-assessment (Case 3).

Projects encouraged teacher educators to open up additional opportunities for professional growth in a wider international context, apart from regular workload demands in the home institution. As a project is a unique time-related process undertaken to achieve the set aim and objectives within a defined period of time (International Standards Organisation, 2017), it should be noted that the lifetime of the described projects was concurrent. Case 1 and Case 2 revealed that any intellectual contribution and project related activity required the teacher educators' additional time commitment and increased workload. However, it was a professionally rewarding experience, especially when the key actions, project goals, objectives and timelines were clear and the expected project results and benefits contributed to the current student teachers' study process.

Consequently, a multi-project environment provided greater learning and development opportunities for more teacher educators and various student groups in the home institution, either being encouraged to support the project related activities during the piloting phase of the intellectual output (Case 1 and 2) or to participate in project dissemination and followup events (Case 1, 2 and 3). In addition, it is priceless when the teacher education institution meets the international and strategic aspirations of being recognised for research and innovation and sees the professional, research and teaching related benefits from international engagements of academics and students, promoting even short-term intensive programmes abroad, as in Case 3. The students, involved in mobility programmes, are likely to become open and internationally minded teachers in future.

\section{Conclusions}

1. This study revealed that teacher educators' openness to participation in international projects conforms to home institution's internationalisation strategy where collaboration initiatives are valued, encouraged and supported. 
2. A partnership experience can be professionally rewarding; however, it requires additional time commitment and increased workload.

3. Participation in international projects is worth the effort and contribution if academics foresee and understand how the intellectual output, project dissemination and follow-up events can provide a better study experience for students and benefits for professional development of teacher educators.

4. The focus of collaborative partnerships in teacher education is on knowledge sharing, exploration of best practices, research for bridging theory and practice, and technology enhanced learning innovations.

\section{References}

Augstskolu likums (Law on Institutions of Higher Education) (1995-2018). Rīga: Latvijas Vēstnesis. Retrieved from https://likumi.lv/ta/id/37967-augstskolu-likums.

Babelium Team (2015). Babelium Project Trainer's Guide. An Innovative ICT-based Learning Methodology for Second-language Oral Expression Practice. Retrieved from http:// llp.babeliumproject.com.

Blackmore, P., \& Blackwell, R. (2003). Academic Roles and Relationships. In: R. Blackwell, \& P. Blackmore (Eds.), Towards Strategic Staff Development in Higher Education (pp. 16-28). Maidenhead: SRHE and Open University Press.

Blūma, D. (2016). Skolotāju izglitīiba Latvijā paradigmu mainas kontekstā (1991-2000) (Teacher Education in the Context of Paradigm Shift in Latvia (1991-2000)). Izglitïbas pētniecība Latvijā, Nr. 9. Rīga: LU, PPMF, IPI.

Boyer, E. L. (1990). Scholarship Reconsidered. Priorities of the Professoriate. New York: Jossey-Bass Publishers.

Cohen, R., \& Kennedy, P. (2013). Global Sociology. Third Edition. London: Palgrave Macmillan.

Creamer, E. G. (2004). Assessing the Outcomes of Long-term Research Collaboration. The Canadian Journal of Higher Education, 34(1), 24-41.

Duffield, S., Olson, A., \& Kerzman, R. (2013). Crossing Borders, Breaking Boundaries: Collaboration Among Higher Education Institutions. Innovative Higher Education, 38, 237-250.

Eddy, P. L., \& Garza Mitchell, R. L. (2012). Faculty as Learners: Developing Thinking Communities. Innovative Higher Education, 37, 283-296.

European Commission. (2013). Report to the European Commission on Improving the Quality of Teaching and Learning in Europe's Higher Education Institutions. Luxembourg: Publications Office of the European Union.

Freedman, S., \& Katz, L. (2007). Critical Success Factors for International Projects. PM World Today, 9(10), 1-8.

Greene, J. C. (2009). Meaningfully Engaging with Difference Through Mixed Methods Educational Evaluation. In: K. E. Ryan, \& J. Bradley Cousins (Eds.) The SAGE International Handbook of Educational Evaluation (pp. 323-340). Thousand Oaks, Ca: SAGE Publications, Inc. 
Heffernan, T., \& Poole, D. (2005). In: Search of "The Vibe": Creating Effective International Education Partnerships. Higher Education, 50, 223-245.

Higgs, B., \& McCarthy, M. (Eds.) (2008). Emerging Issues II: The Changing Roles and Identities of Teachers and Learners in Higher Education. Dublin: NAIRTL.

Husso, M. L., Korpinen, E., \& Asunta, T. (2006). Teacher Researcher Net - A Forum of Interactive Professionalism and Empowerment. In: R. Jakku-Sihvonen, \& H. Niemi (Eds.) Research-based Teacher Education in Finland. Reflections by Finnish Teacher Educators (pp. 103-121). Turku: Finnish Educational Research Association.

International Standards Organisation (2017). ISO 10006. Quality Management. Guidelines for Quality Management in Projects. $3^{\text {rd }}$ edition. Geneva: International Standards Organisation.

Jarchow, E. (1997). The Dean's Role in Infusing Global Perspectives Throughout a College of Education. In: M. M. Merryfield, E. Jarchow, \& S. Pickert (Eds.) Preparing Teachers to Teaching Global Perspectives, A Handbook for Teacher Educators (pp. 209-225). London: SAGE Publications Ltd.

Klecka, C. L., Donovan, L., Venditti, K. J., \& Short, B. (2008). Who Is a Teacher Educator? Enactment of Teacher Educator Identity through Electronic Portfolio Development. Action in Teacher Education, 29(4), 83-91.

Merriam, S. B. (1998). Qualitative Research and Case Study Application in Education. San Francisco, CA: Jossey-Bass Publishers. 